\title{
Aplikasi Teknologi Pakan Ternak Sapi melalui Integrasi Sawit-Sapi untuk Mendukung Penyediaan Protein Hewani
}

\author{
(Cattle Feed Technology Application through Cattle-Palm Integration to Support the \\ Provision of Animal Protein)
}

\author{
Arianto A \\ Pusat Teknologi Produksi Pertanian, Badan Pengkajian dan Penerapan Teknologi \\ LABTIAB-Kawasan Puspiptek Serpong Gedung 612, Tangerang Selatan, Banten 15314 \\ arief.arianto@bpt.go.id.
}

\begin{abstract}
This paper aims to discuss the results of the assessment of cattle feed technology to accelerate the increase of beef production as a source of animal protein. Ministry of Health reported that in 2015 there are 404 districts/cities in Indonesia who suffer from malnutrition. The condition of malnutrition in Indonesia is also happening in children less than 5 years old which is the future of this nation which is classified as very apprehensive. Based on the value of the Global Hunger Index (GHI) in 2016, Indonesia falls into the category of serious hunger. According to the Ministry of Agriculture, the fulfillment of food requirement from livestock protein sources will be deficit because the demand level is $3.61 \%$ higher than the average production rate of $1.54 \%$. It is estimated that by 2024 there will be a shortage of 1.045 million tons of beef supply, with the share of domestic meat production decrease to $52.25 \%$. Compared to other countries in ASEAN, beef consumption in Indonesia is very low. Beef consumption levels in Malaysia or Singapore have reached about $15 \mathrm{~kg} /$ capita/year, while Indonesia consumes only about $2.2 \mathrm{~kg} / \mathrm{capita} / \mathrm{year}$. Therefore, the Agency for Assessment and Application of Technology in accordance with its competence conduct assessment one of them is animal feed technology. The assessment of cattle feed technology was done through a cattle-palm oil integration model using raw materials from leaf/branch, by product and decanter solid that can be utilized for cheap, easy and quality animal feed to increase the population and beef production. Fulfillment of community protein needs, is expected to affect the healthier society and educate the nation.
\end{abstract}

Key Words: Feed Technology, Cattle-Palm Integration, Animal Protein

\begin{abstract}
ABSTRAK
Makalah ini bertujuan untuk membahas hasil pengkajian teknologi pakan ternak sapi untuk mempercepat peningkatan produksi daging sapi sebagai sumber protein hewani. Kementerian Kesehatan melaporkan bahwa pada tahun 2015 terdapat 404 kabupaten/kota di Indonesia yang mengalami gizi buruk. Kondisi kekurangan gizi di Indonesia banyak pula terjadi pada anak balita yang merupakan masa depan bangsa ini yang tergolong sudah sangat memprihatinkan. Berdasarkan atas nilai Global Hunger Index (GHI) pada tahun 2016, Indonesia termasuk dalam kategori kelaparan serius. Menurut Kementerian Pertanian, pemenuhan kebutuhan pangan sumber protein asal ternak akan terus mengalami defisit yang semakin membengkak karena laju permintaan (demand) sebesar rata-rata 3,61\% yang lebih besar dibandingkan dengan laju produksi sebesar rata-rata sebesar 1,54\%. Diprediksi pada tahun 2024 akan terjadi kekurangan pasokan daging sapi sebesar 1,045 juta ton dengan share produksi daging dalam negeri yang semakin menurun menjadi sebesar 52,25\%. Dibandingkan dengan negara-negara lain di ASEAN, konsumsi daging sapi di Indonesia termasuk sangat rendah. Tingkat konsumsi daging sapi di Malaysia atau Singapura sudah mencapai sekitar $15 \mathrm{~kg} / \mathrm{kapita} / \mathrm{tahun}$, sementara Indonesia hanya mengkonsumsi sekitar 2,2 kg/kapita/tahun. Oleh karena itu, Badan Pengkajian dan Penerapan Teknologi sesuai dengan kompetensinya terus melakukan pengkajian salah satunya adalah teknologi pakan ternak sapi. Pengkajian teknologi pakan sapi dilakukan melalui model integrasi sawit-sapi dengan
\end{abstract}


menggunakan bahan baku dari serasah daun/dahan kelapa sawit, bungkil inti sawit dan solid decanter yang dapat didayagunakan menjadi pakan ternak yang murah, mudah dan berkualitas untuk meningkatkan populasi dan produksi daging sapi. Terpenuhinya kebutuhan protein masyarakat, diharapkan akan berdampak semakin menyehatkan masyarakat dan mencerdaskan kehidupan bangsa.

Kata Kunci: Teknologi Pakan, Integrasi Sawit-Ternak, Protein hewani

\section{PENDAHULUAN}

Pemenuhan pangan yang berkualitas merupakan salah satu program pemerintah Indonesia saat ini yang dilakukan untuk memenuhi kebutuhan konsumsi masyarakat yang semakin lama semakin meningkat dan sekaligus mencerdaskan dan meyehatkan kehidupan bangsa. Hal ini dilakukan sesuai dengan amanat Undang-Undang No. 18 Tahun 2012 yang menyatakan bahwa pemerintah berkewajiban untuk meningkatkan pemenuhan kuantitas dan kualitas pangan masyarakat. Apalagi Indonesia merupakan salah satu dari 43 negara yang tergabung dalam scalling up nutrition (SUN) yang berkomitmen untuk menangani percepatan perbaikan gizi terutama pada ibu hamil dan menyusui (Bappenas 2013). Terkait dengan kecukupan gizi ini pemerintah Indonesia melalui Kementerian Pertanian tidak hanya menargetkan swasembada daging sapi tetapi juga kecukupan protein hewani.

Salah satu program untuk memenuhi kebutuhan protein untuk perbaikan gizi masyarakat adalah melalui penyediaan daging yang bersumber dari sapi potong. Daging sapi merupakan komoditas potensial yang menyumbang $18 \%$ terhadap konsumsi daging nasional (Matondang \& Rusdiana 2013). Oleh karena itu, ketersediaan daging sapi dengan harga yang terjangkau harus menjadi perhatian pemerintah. Di samping itu, daging sapi merupakan salah satu sumber protein potensial yang mengandung sebanyak $24 \%$ protein. Manfaat daging sapi tidak hanya sebagai penambah lezatnya makanan saja tetapi juga mengandung berbagai vitamin yang bermanfaat bagi kesehatan juga membantu perkembangan otak sehingga berperan dalam mencerdaskan kehidupan bangsa.

Jumlah penduduk Indonesia yang semakin meningkat dan meningkatnya kesadaran masyarakat terhadap pentingnya protein hewani menyebabkan konsumsi protein hewani, khususnya daging sapi meningkat juga. Direktorat Jenderal Peternakan dan Kesehatan Hewan menyatakan bahwa konsumsi daging sapi per kapita tahun 2015 sebesar 0,417 kg mengalami peningkatan sebesar 60,0\% dari konsumsi tahun 2014 sebesar 0,261 kg (Kementan 2016). Permintaan daging sapi yang terus meningkat ini tidak diimbangi dengan peningkatan produksi daging sapi dalam negeri sehingga ketersediaan daging sapi secara nasional masih kurang. Dengan demikian laju produksi daging sapi belum bisa mengimbangi laju konsumsi dalam negeri meskipun Indonesia telah mencanangkan Program Percepatan Swasembada Daging sapi (P2SDS). Oleh karena itu, pemerintah melakukan impor sapi dan daging sapi sekitar 35\% dari kebutuhan daging sapi secara nasional (Atmakusuma et al. 2014).

Tidak seimbangnya neraca daging sapi dan kerbau tahun 2017 yang menyebutkan bahwa konsumsi daging nasional permintaannya melebihi dari ketersediaannya. Konsumsi per kapita daging yaitu $2,75 \mathrm{~kg} /$ tahun yang dipenuhi dari produksi dalam negeri sebersar 437,300 ton daging atau setara dengan 2,57 juta ekor sapi dan dari daging impor sebesar 141.463 ton atau setara dengan 707.000 ekor sapi (Ditjen PKH 2017). Selama ini, kebutuhan daging sapi di Indonesia dipenuhi dari tiga sumber yaitu sapi lokal, sapi impor dan daging impor (Hadi \& Ilham 2000). Berdasarkan road map pencapaian swasembada daging sapi tahun 2014, ditargetkan penyediaan daging sapi produksi lokal sebesar 420,3 ribu ton (90\%) dan dari impor sapi bakalan setara 
daging serta impor daging sebesar 46,6 ribu ton (10\%) (Blue Print P2SDS 2014). Oleh karena itu, diperlukan usaha untuk peningkatan populasi ternak untuk mencukupi kebutuhan protein hewani asal ternak tersebut. Saat ini, pemerintah RI memberikan program prioritas nasionalnya melalui RPJMN, RKP nasional dan program Nawacita pemerintahan era Presiden Jokowi untuk peningkatan penyediaan pangan dari sumber protein hewani asal ternak yaitu dengan target sebesar 700 ribu ton daging per tahun.

Terkait hal ini pemerintah terus berupaya untuk memenuhi kecukupan kebutuhan protein hewani khususnya berasal dari daging sapi hingga mencapai swasembada. Melalui Program Percepatan Swasembada Daging Sapi (PSDS) pemerintah telah memberlakukan lima kebijakan baru yaitu: (1) Penyediaan sapi bakalan/daging sapi lokal; (2) Peningkatan produktivitas dan reproduktivitas ternak sapi lokal; (3) Pencegahan pemotongan sapi betina produktif; (4) Penyediaan bibit sapi lokal; dan (5) Pengaturan stok daging sapi dalam negeri (Rivani \& Rafika 2010). Untuk menunjang kebijakan tersebut, pemerintah dalam beberapa tahun terakhir telah mengurangi biaya sewa lahan Perhutani untuk ladang penggembalaan sapi, menghilangkan biaya bea masuk impor indukan, memberikan bantuan inseminasi buatan secara gratis, merubah kebijakan impor sapi dari country based menjadi zona based dan mengembangkan 50 Sentra Peternakan Rakyat (SPR) (Sinar Tani 2016).

Pemerintah telah mencanangkan program swasembada daging sapi pada tahun 2014, selain untuk mewujudkan ketahanan pangan hewani asal ternak berbasis sumber daya lokal, juga merupakan peluang untuk mengembalikan Indonesia sebagai eksportir sapi seperti pada masa lalu. Namun, gaung swasembada daging sapi masih jauh dari kenyataan bahkan terjadi defisit daging sapi yang cenderung semakin besar. Oleh karena itu, berbagai upaya dilakukan untuk meningkatkan produksi daging sapi di dalam negeri dimana salah satunya adalah pengembangan ternak sapi melalui integrasi sapi sawit. Untuk menunjang peningkatan populasi sapi maka program integrasi sapi sawit ini dapat menambah ketersediaan lahan penggembalaan sapi yang masih terbatas. Melalui model integrasi sapi sawit ini memiliki potensi yang sangat besar dalam penyediaan pakan yang murah dan mudah berupa seresah daun dan dahan kelapa sawit, limbah bungkil sawit dan solid decanter yang dapat didayagunakan menjadi pakan ternak yang berkualitas.

Kementerian Pertanian terus mendorong pengembangan SPR dan ditargetkan sampai tahun 2018 akan terbentuk 1.000 SPR (Kementan 2015). Lebih lanjut, untuk mengejar tercapainya swasembada protein pemerintah telah melakukan upaya penambahan populasi sapi di Indonesia. Pada tahun 2017 pemerintah menargetkan 3,2 juta ekor sapi betina bunting. Target ini bisa tercapai dengan adanya dukungan pengadaan pakan dan lahan yang mencukupi.

Salah satu solusi alternatif yang sangat memungkinkan adalah pemanfaatan potensi perkebunan kelapa sawit sebagai bahan pakan untuk ternak sapi. Indonesia termasuk negara produsen sawit terbesar di dunia. Ditjenbun Kementan mencatat Indonesia memiliki perkebunan kelapa sawit dengan luas areal mencapai 11,3 juta ha. Potensi kelapa sawit ini sangat mendukung pengembangan populasi sapi di Indonesia melalui program integrasi sapi sawit. Hal ini terjadi karena beberapa bagian dari tanaman kelapa sawit dapat dimanfaatkan sebagai pakan ternak antara lain daun, pelepah, tandan kosong, serat perasan dan hasil samping proses pengolahan minyak sawit yaitu solid dan bungkil inti sawit (BIS) sekitar 10 ton BK/ha (Matondang \& Thalib 2015).

Saat ini, $78,25 \%$ populasi ternak sapi terkonsentrasi di wilayah non-sentra sawit seperti Jawa, Bali, Nusa Tenggara dan Sulawesi, sedangkan $21,75 \%$ berada di wilayah sawit (Kalimantan dan Sumatera). Di sisi lain Indonesia memiliki 11,3 juta ha perkebunan sawit yang berpotensi untuk mendukung perkembangan populasi sapi nasional melalui 
sistem integrasi sapi-sawit. Setiap hektar perkebunan sawit memiliki biomassa yang dapat memenuhi kebutuhan nutrisi (pakan) satu ekor ternak sapi dewasa selama setahun penuh. Apabila diasumsikan hanya 30\% lahan kelapa sawit yang dapat digunakan untuk program integrasi ternak sapi, maka ada sekitar 3 juta ha yang dapat menampung 3 juta ekor ternak sapi potong.

Badan Pengkajian dan Penerapan Teknologi (BPPT) melalui unit Pusat Teknologi Produksi Pertanian (PTPP-TAB) mempunyai salah satu kegiatan Teknologi Produksi Peternakan yang direncanakan dalam rencana stragetis (Renstra) BPPT, Renstra TAB dan dijabarkan dalam Rencana Kegiatan unit PTPP. Kegiatan pengkajian dan penerapan teknologi mempunyai kegiatan inovasi teknologi produksi pangan sumber protein hewani dengan sub-kegiatan pengembangan dan pemanfaatan teknologi pakan ternak berbasis limbah industri kelapa sawit. Oleh karena itu, BPPT sesuai dengan kompetensinya akan melakukan pengkajian kebijakan untuk mendukung tercapainya swasembada protein di Indonesia. Pencapaian swasembada daging sapi tidak dapat diselesaikan secara parsial tetapi membutuhkan sinergitas dari berbagai pihak yang terkait. Hasil pengkajian ini diharapkan sebagai bahan masukan kepada pemerintah untuk mengatasi berbagai persoalan yang dihadapi guna mencapai swasembada protein secepatnya untuk mencerdaskan kehidupan bangsa.

Dilaporkan bahwa implementasi program integrasi sawit-sapi di Indonesia baru mencapai $0,5 \%$, meskipun berbagai upaya telah dilakukan pemerintah. Mempertimbangkan bahwa usaha sapi merupakan hal baru bagi para pekebun, maka upaya pengawalan dan pendampingan dalam integrasi sawit-sapi menjadi sangat penting. Sapi Bali menjadi andalan dalam usaha integrasi sawit-sapi yang mulai diluncurkan oleh pemerintah sejak tahun 2007 (Soedjana 2015).

Model pengembangan sapi Bali pada sistem integrasi sawit-sapi pada sistem pemeliharaan intensif, semi intensif dan ekstensif mampu meningkatkan produktivitas dan populasi sapi Bali, memberikan tambahan penghasilan dari hasil penjualan sapi, meningkatkan hasil panen dan penjualan TBS, memanfaatkan kotoran sapi sebagai pupuk organik dan mengurangi jumlah tenaga kerja. Pengembangan sapi Bali melalui integrasi dengan perkebunan kelapa sawit memberikan prospek yang menjanjikan dan diharapkan dapat mewujudkan program nasional guna meningkatkan populasi sapi di dalam negeri.

\section{DASAR HUKUM DAN STATE OF THE ART TECHNOLOGY}

Pengembangan kegiatan integrasi sawit sapi sangat mendukung program Nawacita Presiden Jokowi Nomor 7: Mewujudkan kemandirian ekonomi dengan menggerakan sektor-sektor strategis ekonomi domestik bidang peternakan serta mendukung program prioritas nasional produksi daging sapi 710 ribu ton. Badan Pengkajian dan Penerapan Teknologi sesuai dengan fungsinya seperti dalam Buku II RPJMN 2015-2019 pada halaman 4-24, 37, 86 mendapat tugas untuk alih teknologi dan diseminasi hasil riset yang berhasil di skala laboratorium seperti sistem peternakan modern, teknologi olahan daging dan susu, olahan silase dan teknologi produksi ternak melalui alih teknologi kepada publik.

Payung hukum kegiatan integrasi sapi sawit telah dibuat dalam bentuk Permentan Nomor 105/Permentan/PD.300/8/2014 tentang Integrasi Usaha Perkebunan Kelapa Sawit dengan Usaha Budidaya Sapi Potong. Namun demikian, kegiatan ini belum terdengar gaungnya secara nasional karena kegiatan yang dilakukan masih bersifat sporadis, belum terkoordinasi dengan baik dan masih banyak menghadapi kendala terutama di sektor hilir yakni segi pendanaan, perbankan dan dari segi kebijakan.

Teknologi peternakan sistem integrasi antara produksi peternakan ruminansia dengan industri kepala sawit merupakan salah satu alternatif usaha pengembangan jumlah 
populasi ternak ruminansia di Indonesia melalui peningkatan bibit ternak yang dapat di kembangkan pada luasan areal perkebunan sawit. Beberapa inovasi teknologi produksi peternakan pada sistem intgerasi tersebut saling berhubungan membentuk suatu model sistem integrasi yang dapat meningkatkan produktifitas ternak. Di samping itu, teknologi sistem integrasi yang diaplikasikan juga melingkupi dampak kegiatan sistem integrasi pada usaha perkebunan sehingga manajemen pengelolaan dampak integrasi juga merupakan sebuah inovasi untuk mendapatkan usaha integrasi yang saling menguntunngkan antara kedua sektor pertanian dan peternakan.

State the art of tehcnology sistem integrasi pada teknologi produksi peternakan menghasilkan beberapa inovasi teknologi beberapa bidang keilmuan yang dapat di aplikasikan pada sistem integrasi dengan tujuan untuk meningkatkan produktivitas kedua usaha yang terlibat (peternakan dan perkebunan). Hubungan antara inovasi teknologi peternakan pada sistem integrasi tersebut dapat dijelaskan dalam rangkaian state the art of technology seperti pada Gambar 1 di bawah ini.

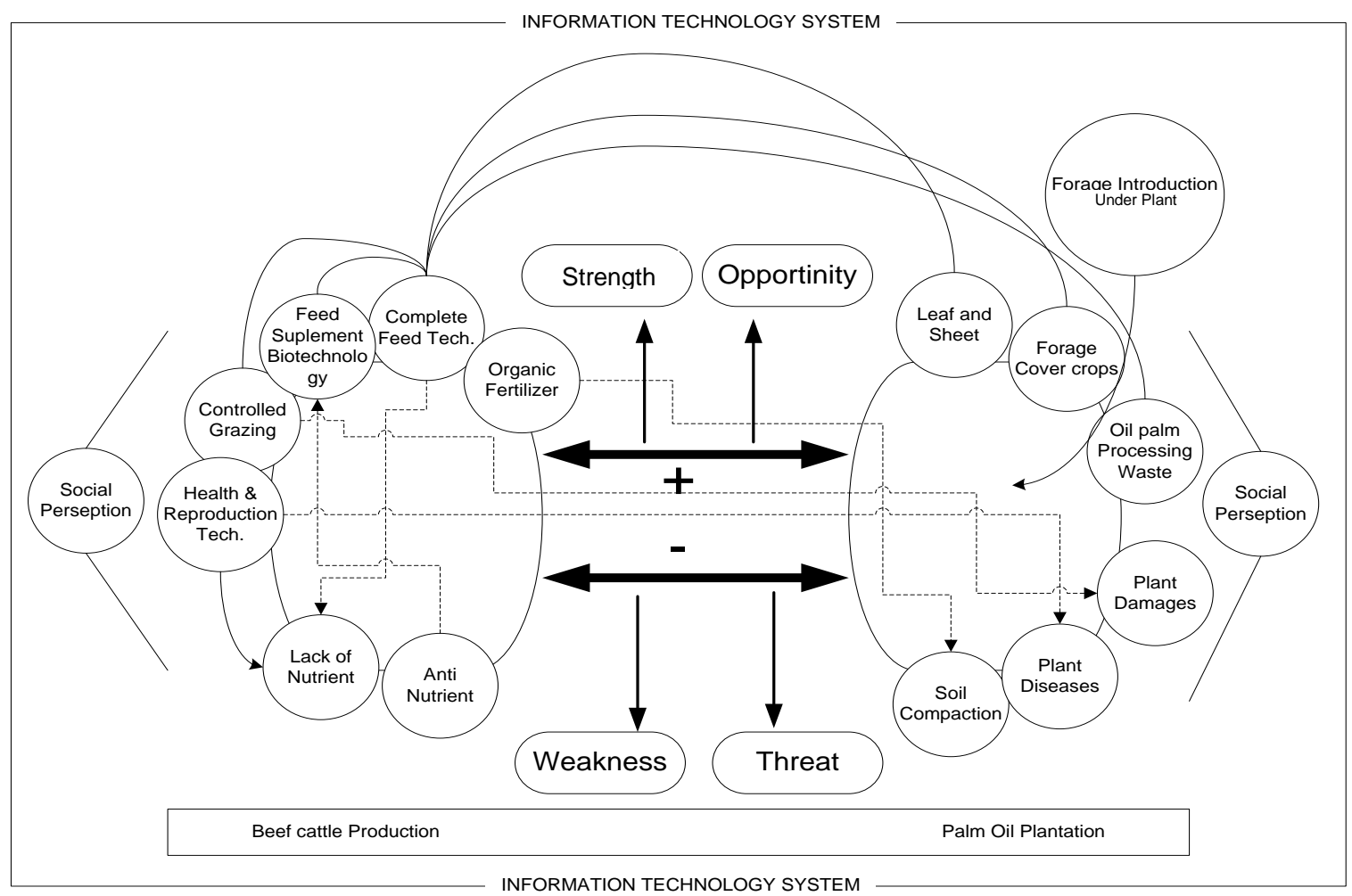

Gambar 1. Rangkaian teknologi inovasi produksi peternakan sistem integrasi membentuk state the art of technology beberapa bidang teknologi yang mempertimbangkan aspek kekuatan, kelemahan, tantangan dan potensinya

Pada teknologi sistem integrasi, beberapa faktor input produksi yaitu faktor bakalan/bibit, faktor pakan dan faktor manajemen pengelolaan reproduksi dan kesehatan dapat diperoleh dari sumber wilayah yang dikembangkan. Faktor pakan sebagai faktor terbesar dari usaha peternakan dan sangat mempengaruhi tingkat keberhasilan usaha peternakan dapat diperoleh dengan mudah dari beberapa bahan yang ada di lingkungan industri sawit. Sehingga bahan pakan tersebut dapat diperoleh dengan harga murah dan tersedia secara terus menerus. Bibit ternak unggul dari ternak lokal Indonesia yang dikembangkan pada sistem integrasi akan diperoleh sebagai sumber bakalan usaha peternakan. Keuntungan bakalan lokal tersebut adalah bakalan ternak yang sangat adaptif 
terhadap lingkungan alami habitat Indonesia sehingga tidak perlu mendatangkan bakalan ternak dari luar yang belum teruji.

\section{PROGRAM INOVASI TEKNOLOGI BPPT PADA INTEGRASI SAWIT SAPI}

\section{Kajian produksi pakan komplit}

Pakan merupakan sendi penting dalam peningkatan populasi dan produktivitas ternak, sehingga diperlukan daya inovasi-inovasi teknologi untuk menjamin ketersediaan pakan sepanjang tahun. Perubahan musim yang terkadang ekstrim sering menimbulkan masalah ketersediaan pakan, terutama bagi peternak-peternak yang mengandalkan pasokan pakan dari alam (rumput liar). Pemanfaatan limbah/hasil ikutan pertanian menjadi satu solusi strategis dan bijak dalam mengatasi ketersediaan pakan. Gambaran produk inovasi yang dikerjakan BPPT terlihat dalam Gambar 2.

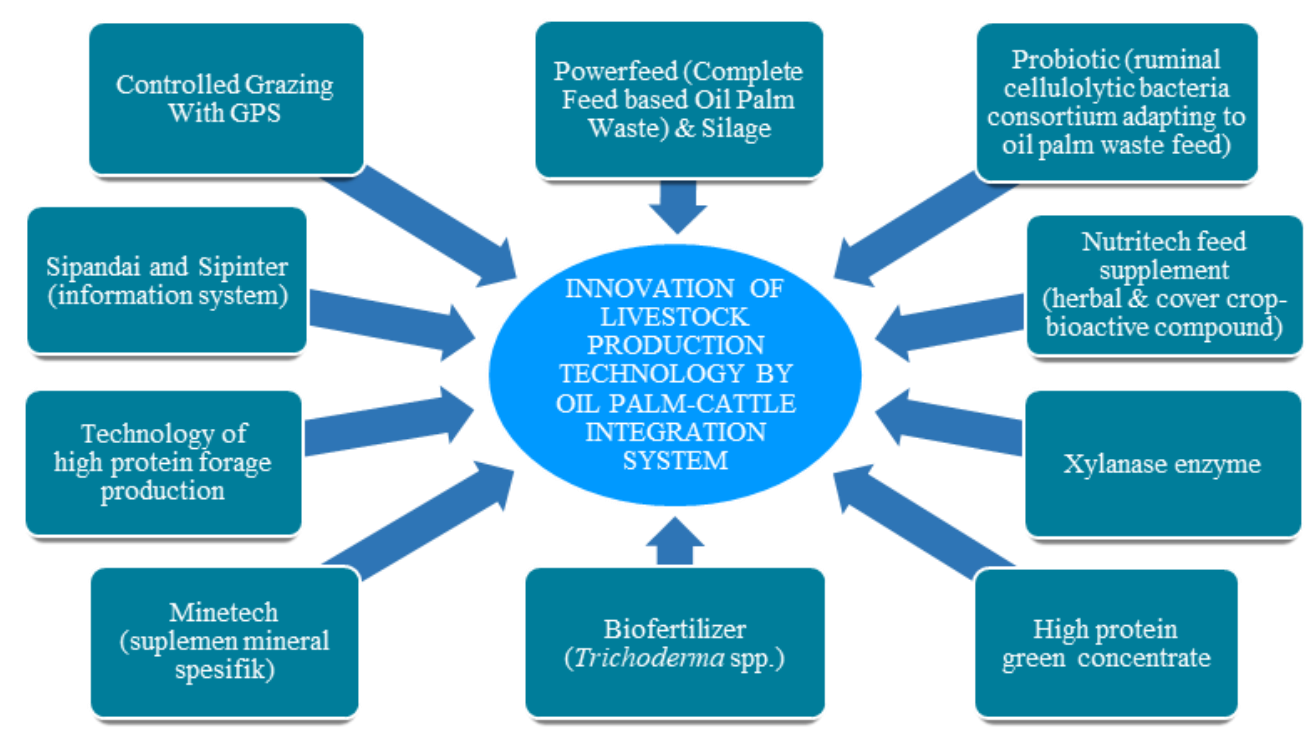

Gambar 2. Produk inovasi teknologi pakan BPPT

Produk samping dan hasil ikutan industri perkebunan terus bertambah jumlahnya seiring dengan makin luasnya areal perkebunan. Salah satu perkebunan yang cukup luas arealnya dengan laju pertumbuhan $12,6 \%$ per tahun adalah perkebunan kelapa sawit. Pemanfaatan hasil samping perkebunan terutama perkebunan sawit menjadi salah satu peluang besar untuk penyediaan pakan ternak alternatif. Banyak penelitian telah dilakukan untuk memanfaatkan hasil samping industri sawit, bahkan salah satu byproduct industri ini yaitu bungkil sawit telah memiliki nilai ekonomis yang cukup tinggi dan ketersediaan yang terbatas. Maka bukan tidak mungkin suatu saat hasil samping dari industri ini seperti tandan kosong, serat perasan, lumpur sawit/solid, pelepah dan daun sawit yang belum dimanfaatkan secara optimal akan menjadi sumber bahan pakan utama yang memiliki nilai ekonomis yang tinggi dan menjadi solusi untuk meningkatkan produktivitas sapi lokal secara nasional.

Badan Pengkajian dan Penerapan Teknologi sejak tahun 2014 telah melakukan berbagai kegiatan untuk mensosialisasikan pemanfaat limbah industri sawit, yang dampaknya mempermudah masyarakat peternak di Kabupaten Pelalawan, Riau untuk memperoleh bahan pakan berkualitas. Selain sosialisasi pemanfaatan limbah industri sawit, BPPT juga melakukan berbagai kajian tentang kandungan nutrisi dan formulasi, pengolahan dan penyajian pakan yang tepat untuk mendapatkan hasil optimal. 
Tabel 1. Kandungan nutrisi lengkap limbah sawit

\begin{tabular}{|c|c|c|c|c|c|c|c|c|c|}
\hline \multirow{2}{*}{ Nama Bahan } & \multirow{2}{*}{$\mathrm{BK}(\%)$} & $\mathrm{BO}$ & Abu & PK & Lemak & SK & BETN & NDF & ADF \\
\hline & & \multicolumn{8}{|c|}{------------------------------ \% BK -------------------------- } \\
\hline Pelepah daun sawit & 47,06 & 90,35 & 9,65 & 4,45 & 2,56 & 41,14 & 42,21 & 74,11 & 59,43 \\
\hline Pelepah sawit & 33,93 & 98,03 & 1,97 & 1,40 & 1,22 & 48,12 & 47,29 & 73,35 & 57,47 \\
\hline Daun sawit & 43,80 & 95,57 & 4,43 & 9,24 & 4,29 & 33,04 & 49,00 & 59,64 & 45,44 \\
\hline Covercrop 7 & 31,56 & 78,21 & 21,79 & 16,93 & 6,67 & 36,23 & 18,38 & 62,74 & 49,11 \\
\hline Covercrop 10 & 31,84 & 84,16 & 15,84 & 6,92 & 2,18 & 33,97 & 41,10 & 71,09 & 50,76 \\
\hline Covercrop 14 & 32,24 & 84,39 & 15,61 & 7,17 & 2,54 & 36,15 & 38,53 & 67,10 & 52,79 \\
\hline Press fiber SLS & 92,00 & 94,90 & 5,10 & 5,07 & 8,26 & 47,75 & 33,82 & 85,75 & 66,15 \\
\hline Bungkil sawit SLS & 83,60 & 95,68 & 4,32 & 13,54 & 16,24 & 23,53 & 42,37 & 78,85 & 56,17 \\
\hline Lumpur sawit padat & 22,27 & 61,20 & 38,80 & 22,11 & 0,89 & 8,51 & 29,69 & 63,90 & 67,08 \\
\hline Solid ex decanter & 21,72 & 90,47 & 9,53 & 17,50 & 11,92 & 31,32 & 29,73 & 64,77 & 56,45 \\
\hline Dedak padi & 89,45 & 82,64 & 17,36 & 5,51 & 5,77 & 29,58 & 41,78 & 55,40 & 49,36 \\
\hline Rataan covercrop & 31,88 & 82,26 & 17,74 & 10,34 & 3,80 & 35,45 & 32,67 & 66,98 & 50,89 \\
\hline Mucuna & 16,00 & 92,21 & 7,79 & 17,78 & 11,92 & 27,72 & 44,95 & 62,90 & 41,48 \\
\hline Rumput Kumpay & 30,67 & 92,66 & 7,34 & 4,56 & 1,49 & 37,15 & 49,45 & 82,81 & 49,53 \\
\hline
\end{tabular}

BK: Bahan kering; BO: Bahan organik; PK: Protein kasar; SK: Serat kasar; BETN: Bahan ekstrak tanpa nitrogen; NDF: Neutral detergent fiber; ADF: Acid detergent fiber

Sumber: Rofiq et al. (2015) unpublished

Masalah yang dihadapi dalam pemanfaatan pakan berbahan baku limbah sawit adalah penyimpanan dan pengemasan. Sebagian besar limbah industri sawit memiliki kandungan air yang cukup tinggi sehingga dalam penyimpanannya memerlukan tempat yang khusus. Selain itu, pakan yang basah memiliki daya tahan yang rendah dan pengangkutan yang relatif sulit sehingga perlu penanganan dan pengolahan yang baik untuk mengatasi masalah tersebut.

Dalam upaya mengatasi permasalahan ketersediaan pakan dan meminimalkan kelemahan kelemahan dalam penyimpanan pakan, maka sangat penting dicari satu terobosan teknologi yang tidak hanya dapat menyediakan pakan secara berkelanjutan tetapi juga dapat mempermudah peternak dalam memberikan pakan pada ternaknya. Teknologi silase ransum komplit merupakan jawaban yang tepat untuk mengatasi permasalahan tersebut di atas.

\section{Rekayasa desain penggembalaan terkontrol pada sistem integrasi sapi sawit}

Pengembangan perkebunan kelapa sawit berkelanjutan sebagai bagian dari pembangunan ekonomi ditujukan untuk meningkatkan pendapatan masyarakat, meningkatkan penerimaan negara, meningkatkan devisa negara, menyediakan lapangan kerja, meningkatkan produktivitas, nilai tambah dan daya saing, memenuhi kebutuhan konsumsi dan bahan baku industri dalam negeri, serta mengoptimalkan pengelolaan sumber daya alam secara lestari. Konsep sistem integrasi sawit-sapi adalah saling memanfaatkan dari subsistem perkebunan kelapa sawit dan/atau pabrik kelapa sawit dengan subsistem usaha ternak sapi sehingga dihasilkan manfaat ganda.

Alternatif pengembangan sistem integrasi sawit-sapi untuk usaha perkembangbiakan dan penggemukan dapat dilakukan melalui pola digembalakan (grazing) atau 
dikandangkan. Grazing secara terbatas dan terkendali hanya dapat dilakukan bila dapat dipastikan sapi tidak merusak tanaman dan tidak menimbulkan penyebaran penyakit pada lahan sawit dengan tanaman yang sudah menghasilkan. Daya dukung vegetasi hijauan dari kebun kelapa sawit sebagai sumber pakan maksimum 2 ST per ha. Sistem ini sangat efektif dan efisien, karena biaya pemeliharaan sapi sangat minimum bahkan dapat mendekati zero cost. Adapun pola pengandangan ternak dapat memudahkan dalam pengelolaan kotoran dan urine sapi, serta tidak berdampak negatif terhadap kelestarian kebun.

Permasalahan utama sistem integrasi sawit-sapi belum berkembang adalah karena pemahaman sistem integrasi sapi sawit masih rendah, ditambah lagi muncul kekhawatiran bahwa adanya sapi di kebun sawit akan menyebabkan kerusakan tanaman kelapa sawit. Beberapa faktor penghambat pelaksanaan kegiatan integrasi sapi dengan kelapa sawit antara lain kekurangan tenaga ahli, pengalaman dan pemahaman sehingga pemilik/ manajemen kebun kelapa sawit ragu untuk melaksanakan program integrasi, kekhawatiran terjadi pemadatan tanah, kesulitan dalam pemasaran ternak dan daging ternak serta kekurangan suplai bakalan dan induk produktif.

Akibat dari belum sepenuhnya pelaksanaan integrasi sawit-sapi ini adalah produksi bakalan sapi juga masih rendah, padahal biomassa dari kebun ataupun industri kelapa sawit berpotensi dimanfaatkan sebagai pakan karena ketersediaanya yang melimpah serta kandungan nutrisinya yang cukup tinggi. Disamping itu, banyaknya penelitian dan kajian mengenai integrasi sapi sawit baik di dalam negeri maupun luar negeri sudah banyak dilakukan dengan hasil yang cukup baik merupakan nilai tambah untuk melakukan kegiatan integrasi sapi dengan sawit. Pola penggembalaan sapi di kebun sawit harus dilakukan secara hati-hati agar tidak terjadi berdampak buruk terhadap kondisi kebun kelapa sawit seperti over grazing, pemadatan lahan, kerusakan tanaman kelapa sawit serta penyebaran jamur Ganoderma.

\section{Kegiatan pengelolaan dampak integrasi sawit-sapi}

Dampak integrasi sawit-sapi bertujuan untuk mengidentifikasi permasalahan yang timbul akibat dari penggembalaan sapi di perkebunan kelapa sawit dan cara pengendaliannya. Isu utama dampak negatif penggembalaan sapi di perkebunan kelapa sawit adalah kejadian penyakit busuk pangkal batang (basal stem rot) dan upper steam rot pada kelapa sawit akibat cendawan Ganoderma yang diduga disebarkan oleh sapi. Hipotesis sementara feses sapi diduga membantu penyebaran Ganoderma, namun kebenaran hipotesis ini perlu dibuktikan secara ilmiah.

Deteksi Ganoderma pada tanah sebelum penggembalaan dan feses sapi segar setelah penggembalaan di perkebunan kelapa sawit rakyat telah dilakukan pada tahun 2016. Hasil deteksi menggunakan metode selective medium menunjukkan cendawan yang secara morfologi mirip dengan Ganoderma hanya terdapat pada satu titik lokasi pengambilan sampel di perkebunan kelapa sawit rakyat. Pengamatan morfologi pada feses sapi segar yang telah digembalakan di perkebunan kelapa sawit rakyat tidak menunjukkan keberadaan cendawan Ganoderma.

Kajian penyebaran Ganoderma oleh sapi perlu dilakukan dalam rangka mengetahui berbagai aspek dari sapi dan limbahnya yang menjadi dampak negatif untuk pertumbuhan kelapa sawit. Kajian ini akan menggunakan metode survei di perkebunan kelapa sawit sebelum dan setelah penggembalaan sapi. Hasil kajian akan disusun menjadi suatu rekomendasi awal perkebunan kelapa sawit yang layak untuk diintegrasikan dengan sapi. 
Mikroba tanah yang berasal dari perkebunan kelapa sawit berpotensi dimanfaatkan sebagai soil probiotic sebagai upaya preventif terhadap isu penyebaran Ganoderma. Pengujian secara in vitro telah dilakukan terhadap beberapa cendawan yang berpotensi antagonis terhadap Ganoderma pada tahun 2016. Beberapa cendawan Trichoderma koleksi Laboratorium Proteksi PTPP mampu mengendalikan pertumbuhan Ganoderma boninense asal Pangkalan Bun secara in vitro.

\section{Produksi pakan suplemen}

Pakan berbasis limbah industri sawit ini mengandung serat kasar yang cukup tinggi sehingga hal ini menjadi kendala dalam sistem peternakan integrasi sawit-sapi yang sedang dikaji oleh BPPT di Kabupaten Pelalawan, Riau. Untuk mendukung kajian tersebut, diperlukan beberapa teknologi smart farming berupa probiotik spesifik sawit dan pakan suplemen. Pola peternakan rakyat yang umumnya memanfaatkan hijauan kualitas rendah mengakibatkan hilangnya energi bruto pakan yang dikonsumsi ternak dan terjadi peningkatan produksi gas metan enterik akibat fermentasi pakan yang tidak optimal pada rumen sehingga kecernaan dan produktivitas sapi potong rendah. Manipulasi ekosistem mikroba rumen untuk memperbaiki kecernaan serat limbah sawit dan mengurangi emisi metana merupakan salah satu upaya kajian yang dilakukan BPPT melalui pemanfaatan probiotik spesifik sawit dalam pakan komplit. Probiotik spesifik sawit yang digunakan berasal dari bakteri rumen ternak sapi potong sudah beradaptasi lama dengan memakan limbah kelapa sawit.

Kemampuan ternak sapi dalam mencerna bahan serat lignosellulosa yang berasal dari limbah sawit tidak terlepas dari peranan diversitas mikroba rumen yang sangat besar. Di antara beberapa mikroba rumen ada yang bersifat probiotik yang secara alami terdapat di dalam rumen ternak sapi tersebut. Pakan suplemen yang telah dikaji oleh BPPT pada tahun 2011-2012 berupa pakan suplemen Nutritech yang mengandung agen defaunasi, protein bypass dan minyak esensial. Pada tahun ini, akan dilakukan pengembangan produk pakan suplemen tersebut menjadi Nutritech Optimum. Pakan suplemen ini bersifat multifungsi karena mengandung agen defaunasi/methane inhibitor, minyak esensial, branched chain amino acid, feed intake enhancer, enzyme secretion stimulator dan rumen bypass amino acid, yang diharapkan dapat memenuhi kebutuhan nutrisi ternak sapi potong penggemukan tidak hanya makro nutrisi, juga mikro nutrisi (vitamin, mineral, asam amino) sehingga dapat meningkatkan produktivitas dan mengurangi emisi gas metana enterik sapi potong.

Inovasi produksi pakan suplemen merupakan kegiatan yang akan menghasilkan beberapa produk pakan suplemen yang mengandung bahan bioaktif tanaman dan mikroba yang mempunyai fungsi sesuai dengan aktivitasnya dalam memanipulasi metabolisme ternak ruminansia. Isolat bakteri rumen yang akan dijadikan kandidat probiotik spesifik sawit berfungsi dalam menyeimbangkan populasi mikroba rumen dan bersifat lignoselulolitik yang dapat mendegradasi ikatan lignoselulolitik pada limbah sawit yang terdapat dalam pakan komplit. Pakan suplemen Nutritech Optimum yang bersifat multifungsi yaitu sebagai agen defaunasi (mengurangi populasi sebagian atau seluruh protozoa sehingga archea yang menempel pada dinding protozoa penghasil metan pun dapat dikurangi akibatnya emisi metana enterik ruminansia pun dapat berkurang), sumber asam lemak medium chain fatty acid $(\mathrm{C} 8-\mathrm{C} 12)$ berperan sebagai methane inhibitor, branched chain amino acid (asam amino rantai bercabang yang merupakan penghasil asam lemak rantai cabang yang digunakan untuk stimulasi pertumbuhan populasi mikroba rumen (positif). Feed intake enhancer, enzyme secretor stimulator dan rumen bypass 
amino acid untuk meningkatkan kecernaan, bypass protein, mempercepat reaksi enzim metabolisme rumen, penghasil metabolit bermanfaat yang diproduksi pada daging.

\section{KESIMPULAN}

Dari paparan yang disampaikan beberapa benang merah yang perlu diperhatikan antara lain: (1) Teknologi pakan pada sistem integrasi sawit-sapi harus bertujuan pada penyediaan bahan pakan untuk memenuhi kebutuhan pakan dan nutrisi pada peningkatan populasi ternak; (2) Teknologi pakan pada sistem integrasi sawit harus mempunyai nilai keberlanjutan penyediaan, berkualitas dan ekonomis serta ramah lingkungan; (3) Sinergitas hasil riset teknologi pakan sistem integrasi perlu dilakukan antar institusi terlibat (kerjasama riset dan diseminasi); dan (4) Kemajuan riset dan teknologi untuk ekobioteknologi perlu diaplikasikan pada sistem integrasi sawit-sapi.

\section{DAFTAR PUSTAKA}

Atmakusuma J, Harmini, Winandi R. 2014. Mungkinkah swasembada daging terwujud. Risalah Kebijakan Pertanian dan Lingkungan. 1:105-109.

Bappenas. 2013. Gerakan Nasional Percepatan Perbaikan Gizi. Sumber: http://www.bappenas.go.id /id/profil-bappenas/unit-kerja/deputi-sdm/dit-kgm/contents-direktorat-kesehatan-dan-gizimasyarakat/gerakan-nasional-percepatan-perbaikan-gizi/.

Ditjen PKH. 2017. Pedoman sentra peternakan rakyat (SPR). Jakarta (Indonesia): Direktorat Jenderal Peternakan dan Kesehatan Hewan.

Kementan. 2016. Statistik peternakan dan kesehatan hewan. Jakarta (Indonesia): Direktorat Jenderal Peternakan dan Kesehatan Hewan.

Matondang RH, Rusdiana S. 2013. Langkah-langkah strategis dalam mencapai swasembada daging sapi/kerbau. Bogor (Indonesia): Puslitbangnak.

Rivani E, Sari R. 2010. Kebijakan pencapaian swasembada daging sapi tahun 2014. Jurnal Ekonomi Kebijakan Publik. 2:189-219.

Sinar Tani. 2016. Swasembada protein hewani. Sumber. Majalah Sinar Tani. http://tabloidsinartani.com/content/read/swasembada-protein-hewani/

\section{DISKUSI}

\section{Pertanyaan}

1. Apakah sudah ada informasi pola atau data penyakit di integrasi sapi-sawit?

2. Apakah ada dukungan sistem kesehatan ternak untuk integrasi sawit-sapi tersebut?

3. Bagaimana kotoran sapi juga bermanfaat pada sawit baik secara langsung maupun tidak langsung. Karena apabila bisa, pada integrasi sapi sawit ini, kotoran sapi digunakan untuk pupuk sehingga menghasilkan pohon sawit yang berkualitas sebagai bahan pakan yang berkualitas pula. Bagaimana Bapak menerangkan hal tersebut? 


\section{Jawaban}

1. Penelitian tentang kejadian penyakit sudah ada, temuan dilaporkan ke dinas peternakan setempat. Sebagian kasus ditangani peternak sendiri, apabila ada kejadian mereka langsung melapor ke BPPT.

2. Ada beberapa hal yang perlu dikembangkan tentang veteriner. Misalnya tentang hormon dan vaksin, dari sisi tersebut bisa dilakukan kerjasama dengan Balai Besar Penelitian Veteriner. Di sisi lain BPPT mempunyai beberapa keilmuan yang belum dimanfaatkan di bidang pertanian. Misalnya pengawasan bidang pertanian yang masih dilakukan secara manual padahal kami sudah mengembangkan drone pemantau. Untuk kejadian penyakit yang telah terdeteksi adalah parasit. Selain itu kami mempunyai aplikasi Si Pintar untuk mendeteksi tingkat kejadian penyakit. Sudah diuji di SPR. SPR yang didirikan memiliki karaker-karakter yang baik dan terukur, dan terarah sehingga ketika dimasukkan aplikasi menjadi lebih baik. Nantinya kita bisa kuatkan analisisnya untuk mengatasi meluasnya kejadian penyakit.

3. Kaitannya dengan pemanfaatan limbah sawit sebagai pakan ternak, kotoran sapi selain dijadikan biogas juga dijadikan pupuk organik cair. Dari hasil penjualan pupuk organik cair bahkan kadang lebih besar daripada bisnis ternak itu sendiri. Untuk informasi detailnya ada di teman-teman di tim. 